\title{
PAKISTANI SCHOOLS: A CULTURAL STRUCTURE ANALYSIS
}

\author{
CHITRALI, Jamil Ahmad ${ }^{1}$
}

\begin{abstract}
The aim of this article is to present the need to consider some important facts to deal with the problem of Education, Gender, Radicalization, Documentation of Economy and Democratization of institutions through a program of Education Reforms in Pakistan as a one package. We need to consider out of box, research based on native solutions. One of the more important questions to analyze is the fact that in Pakistan, school system is divided into three tiers. Primary schools; enroll and retain students from grade 1 through grade 5, followed by enrolment in middle schools; (grade 6th to grade 8th) through to, high schools; (grade 9th to grade 10th). In addition to this, there are higher secondary schools, replacing high schools in most cases, which offer enrolment from grade 9th to grade 12th. This last tier is not considered as the fourth one because there is no school exists in the country which offers only grade 9 to 12 educations but this is mostly an attachment or part of school or college to have students beyond grade 10 . The concept was to extend schooling to twelve grades from 10 and colleges only to deal with four years bachelor program that others call undergrad. With densely populated schools and poor infrastructure available you cannot just put in more 25 million, nor can you let them wait till the schools are build and teachers are employed, let the quality of education, poverty, lack of interest from parents, training of teachers compromised.
\end{abstract}

KEYwORDS: School Culture - Education at Pakistan - Democratization of institutions.

\section{RESUMO}

O objetivo deste artigo é apresentar a necessidade de considerar alguns fatos importantes para lidar com o problema da Educação, Gênero, Radicalização, Documentação da Economia e Democratização das instituições através de um programa de Reformas Educacionais no Paquistão como um pacote único. É preciso, para tal, considerar o que está fora da caixa, que trata de resultados de pesquisa que pautem as soluções próprias do país. Uma das questões mais importantes a serem analisadas é o fato de que no Paquistão, o sistema escolar é dividido em três camadas. A Escola Primária; matricula e retém alunos da $1^{\mathrm{a}}$ a $5^{\mathrm{a}}$ série, seguidos pela matrícula em escolas de ensino médio; (da $6^{\circ}$ ao $8^{\circ}$ ano) até o ensino médio; (consideradas as séries $9^{a}$ ao $10^{a}$ ). Além disso, existem escolas secundárias de nível superior, que substituem as escolas de ensino médio na maioria dos casos, oferecem matrícula as séries entre a $9^{a}$ e $12^{a}$ série. Estes últimos níveis não são considerados como o quarto ano

\footnotetext{
${ }^{1}$ University of Peshawar, Pakistan. Email: jamilchitrali@hotmail.com
} 
porque não há nenhuma escola existente no país, que ofereça educação para os anos 9 a 12 , mas isso é principalmente um apego ou parte da escola ou poder para ter alunos que não ultrapassem além da $10^{a}$ série. Estender a escolaridade para doze graus e faculdades seria apenas um problema para lidar com quatro anos de programas de bacharelado que outros países nomeiam como graduação. Com escolas densamente povoadas e infraestrutura deficiente disponível não é possível apenas colocar mais 25 milhões, nem pode deixá-los esperar até que as escolas sejam construídas e os professores sejam empregados e preparados, é preferível deixar a qualidade da educação, a pobreza, a falta de interesse dos pais e a formação de professores em um estado de comprometimento.

Palavras-chave: Cultura escolar - Educação no Paquistão - Democratização das Instituições.

\section{Introduction}

Education Reforms in Pakistan proposed school system divided into three grades. Primary schools; enroll and retain students from grade 1 through grade 5, followed by enrolment in middle schools; (grade $6^{\text {th }}$ to grade $8^{\text {th }}$ ) through to, high schools; (grade $9^{\text {th }}$ to grade $10^{\text {th }}$ ). In addition to this, there are higher secondary schools, replacing high schools in most cases, which offer enrolment from grade $9^{\text {th }}$ to grade $12^{\text {th }}$. This last year is not considered as the fourth one because there is no school in the country which offers only grades $9^{\text {th }}$ to $12^{\text {th }}$ education but this is mostly an attachment or part of school or college to have students beyond grade $10^{\text {th }}$. The concept was to extend schooling to twelve grades from 10 and colleges only to deal with four years bachelor program that others call undergrad.

Pakistani schools, in terms of their internal environment and enrolmentrelated aspects exhibit multiple issues and problems that we are going to discuss briefly to make a case. In Pakistan, addition to public schools, private schools also provide education, which until the beginning of 1990s were only few but since then have mushroomed quite well. The private primary schools have grown more than the middle or high schools. Despite efforts at improving public sector schools' performance ${ }^{2}$ their performance is quite low, rather degenerating, in comparison to private sector schools. Absenteeism of teachers, high dropout rates, low completion rates and high repetition rates, and inequalities of gender, power, class, geography have been identified as persistent problems (SHAH, 2003). With teacher-tostudent ratio of 40:1 in government primary schools (WITTE, EL-BASSEL, GILBERT, WU; CHANG, 2010) in a culture of authoritative teaching techniques it is not unsurprising to know that it is more damaging for children to be in schools than to be out of it; the luckier school students - against the unfortunate children herding animals or scavenging - sitting for hours in congested and crowded environment (MONTERO, 2010) ${ }^{3}$ and being subject to punishment for minor actions such as moving or speaking in class-room, stunt their mental, emotional and physical growth (DFID, 2000, p. 12-13). Around 20,000 public schools do not have ade-

\footnotetext{
2 Since the holding of 'All-education conference (1947) a number of Commission have been formed, e.g. The Commission on National Education (1959), National Education Policy (1970), National Education Policy (1979), and National Education Policy (1992), and Education Sector Reforms as part of Devolution of Power (DOP) various commissions such as 1959 Commission on National Education.
}

\footnotetext{
${ }^{3}$ Montero, Pakistan: The Lost Generation.
} 
quate facilities such as toilets (MONTERO, 2010).

According to Population Council Report (COUNCIL, 2009, p. iv) children attending primary schools are only half of the total schooling-going age children, in secondary schools only quarter of the cohort are in schools and just $5 \%$ of got higher education. Moreover, wide gaps exist in enrolment rates in rural and urban areas. At primary level the enrolment gap between rural and urban areas is $20 \%$, which more than doubles at middle level $(41.4 \%)$, finally reaching $50 \%$ at Matric (high school) level. A more striking fact is that $14 \%$ of girls are enrolled in primary schools and just $8 \%$ girls are enrolled at middle schools (EMIS, 2011, p. 22). In Pakistan, gender differences in school attendance exist in all provinces and in urban and rural areas (SATHAR, LLOYD, METE; UL HAQUE, 2003). According to Sathar's (2003) findings the percentage of respondents attending school increases with higher levels of socioeconomic status. There is relatively small difference in the gap between male and female school attendance in urban areas. Moreover, she found that poverty, especially in urban areas, is a major explanatory variable for differences in school attendance for females in urban areas: in comparison to 88 percent of female adolescents from the highest income group only 23 percent of female adolescents from the lowest income group reported to have attended school. Thus, in the context of urban areas, class rather than gender seems to explain differences in school attendance for girls. However, in rural areas the number of males completing middle school is more than twice the number of females, which means that gender differences are more clearly pronounced: '... only 13 percent of young female students in rural areas complete middle level compared to more than four times that proportion in urban areas' (SATHAR, 2003, p. 50). Although school attainment rates are higher for males in urban areas as well but the gender differences are not that striking as they are in rural areas. Overall, Sathar (2003) concludes that '... fewer than half of all young females aged 15-24 years have ever enrolled in school. Of those who are fortunate enough to gain some education, more are likely to drop out of school at an earlier class than their male counterparts. This pattern of low enrollment for females is magnified at the lowest socioeconomic stratum' (SATHAR, 2003, p.5758).

In 2000 as part of Devolution of Power (DoP) program for transforming local government system, the government of Pakistan initiated Educational Sector Reforms (ESR) for the purpose of 'comprehensive literacy and poverty reduction, expansion of primary elementary education, introduction of technical stream at the secondary level, improving the quality of education through teacher training, forming public private partnership' (SHAH, 2003, p. iv). The situation, however, is anything but better.

As of 2005 , some $33 \%$ of children were enrolled at private schools in Pakistan (AMJAD; MACLEOD, 2012). The mushrooming of private sector schools may generally be seen as a sign of overall improvement in living standard of the people and as ground for supposition that school environment there might be qualitatively more sophisticated.

However, besides the fear that it is leading emergence of class divisions and rifts in terms of employability, creativity and civic engagement their internal dynamics are strongly linked to gender issues. For instance, the largest bulk of students in private schools are boys; only a handful of families would like to send their daughters to schools. This gender discrimination from family side emerges out of socially shared belief that sons are future/old age insurance while a girl's education in private school is devalued be- 
cause she would have to move to husband's house after marriage and hence won't be of that much help to parents (ASLAM, 2006 ${ }^{4}$ ). According to UN $\left(2005^{5}\right)$, $40 \%$ of government schools and $35 \%$ of private schools use corporal punishment. One should not expect violence-free schools in a state that legalize corporal punishment and does not have legal safeguards against sexual harassment. According to Section 89, Pakistan Penal Code 1860 (XLV), parents, teachers and guardians of children are empowered to use "MODERATE CORPORAL PUNISHMENT" as a means to discipline children under the age of 12 years (JONES et al., 2008) ${ }^{6}$. As stated above, because there are no laws safeguarding children against sexual abuse, Plan International (2008) reports to have documented 2500 complaints of sexual abuse against children between 2002 and 2003.

In Pakistani culture, mobility is more, and severely constrained for females than it is for males. Although it is hard to see, but in case, if both the genders are equally (un)constrained, there are yet other important gender dimensions administered to young people by the adults. For instance, once permission is given for outside activities (play, sports, clubbing etc.), young males can move outside home unaccompanied but for young females it is compulsory not to move unaccompanied. Reasons for gender

\footnotetext{
${ }^{4}$ Aslam, M. (2006). The Quality of School Provision in Pakistan: Are Girls Worse off? Retrieved on July 8, 2011, from http://www.gprg.org/pubs/workingpapers/pdfs/gprg -wps-066.pdf

${ }^{5}$ United Nations (2005) Violence against children: regional consultation in East Asia and the Pacific. Geneva: United Nations. In the Painful lessons report.

${ }^{6}$ Jones, N., Karen Moore, Eliana Villar-Marquez, and Emma Broadbent (2008), 'Painful Lessons: The Politics of preventing sexual violence and bullying at school', London: ODI.
}

differences in mobility could be many but, the issue of religion or more specifically, the cultural interpretation of religious values and beliefs seem to a major reason. According to Khan (2004), the imposition of one-dimensional and monolithic version of Islam led to emergence of an ideology that has contributes towards severing mobility for females. Elaborating the argument, He (KHAN, 2004) contends that the injunctions to keep female body covered and hidden and the injunction, to move less in society and the socially created need '..."protect" it from the gaze of outsiders, the fear of its being violated by strangers. These are terms in which men perceive the female body and legislatures, dominated by men, make laws to protect themselves from the havoc that may be wrought upon society if the fitna' located within the female body were to release' (KHAN, 2004, p.10). Such restrictions have serious implications for the attainment of education, accessing health services, opportunities for job/work, as well as for recreation and social networks for young females. In her survey about gender dimension of parenting, Sathar (2003) found that places that parents consider unsafe for young males and females vary. Similarly, parents' fears and reasons for justifying restrictions on the mobility of young males and females also vary. For example, with respect to young males, parental fear circles around the notion of personal safety that is whether they might get physical harm or not. However, with respect to females, the notion of fear is broader than the mere concern for their physical safety: the concern mainly centers on the notion of family reputation and family honor due to loss of virginity of girls (SATHAR, 2003; p. 40-41). The differences in conception of mobility have implications for school attendance, which, for example in 2001, remained 84 percent for

\footnotetext{
7 Translated here as social and moral degeneration leading to violence due to instigation of sex.
} 
male and 54 percent for female adolescents in 2001 (SATHAR, 2003, p. 40-41).

The social values of devaluing girls' education out of concern that they would shift to another house after marriage (COUNCIL, 2009) is perhaps the worst form of violence. Such ideational construct around the girls' education supposedly mean that no matter what happens to a handful of enrolled girls in and around school, parents or community at large would turn blind eye to their problems. This perhaps explains the reasons regarding lack of studies on girls' harassment in and around school. Inside schools the authoritarian teaching methods, punishment and humiliation of children are factors associated with non-attendance and high dropout rates of children from schools in Pakistan (WATKINS, 1999, p. 75). It should also be noted that though no estimates exist as to how much girl students suffer from sexual harassment in and around schools but at least this much is known that most parents would not send their daughters to schools because safeguarding girls' virginity is socially considered as equivalent to safeguarding family honor (UNFPA, 2000) ${ }^{9}$.

The gender based violence in schools and outside, especially sexual harassment, has a religious and minority dimension to it as well. For instance, in many parts of Khyber Pakhtunkhwa province of Pakistan there was and is a myth that to have sex with a sweeper girl $^{10}$ cures backache. Such mythical be-

\footnotetext{
8 Watkins, K. (1999), 'Education Now: Break the Cycle of Poverty', Oxford: Oxfam

9 UNFPA (2000), 'State of World Population Report, the Widespread violence against women in Africa documented,

http://www.afrol.com/Categories/Women/wom003_ violence_unfpa.htm accessed 23rd April, 2010

${ }^{10}$ Cleaning is considered low status job especially public services and hence are mostly performed by Christians in Pakistan being minority.
}

liefs trigger risky behavior among boys who would not hesitate from sexual violence against girls in schools as well as outside schools. This phenomenon also relates to the issue of terrorists' development in Pakistan. The anecdotal evidence and media inspired theory suggests that it is madrasah-system and its curricula that prepare students for terrorist activities. The madrassah which cater for 2 million annual of the school going children constitute $6 \%$ of total school going children in Pakistan. If you consider a child of age 6 to be in school, in Pakistan 4.5 million is the figure that are not going there and 3 million of them are girls. If you count on total under 15 age children going schools, Pakistan has a large number of 25 million out of school in this age bracket out a total expected population of 63 million (35\% of the total population which is 180 million). Both Madrassah and School going in total constitute only $54 \%$ of the school going age and that makes it 36 million totals in number (Fair, 2014). Madsarrah education in Pakistan is considered to constitute $5 \%$ of total formal education enrollments. But before that it is important to note that the ASER (2014) Report published in January 2015 says:

In 2014 both at the rural level only $37 \%$ girls were enrolled in private schools whereas it was $44 \%$ in urban areas. Overall girls remain marginalized and especially those from poorest families, in both public and private schools. A growing concern among households is about where their children will go beyond the primary level? When their children are unable to move from primary to post primary level simply due to lack of schools, parents begin to make hard and angry choices, withdrawing children even prior to primary completion as the future looks very stark and vulnerable for a primary graduate. In public sector for every 8 primary schools there is only 1 middle school and for 11 
primary schools there is only 1 secondary school at the National level (ASER, 2014, p. 8-9).

However, Christine's (2007, p. 100) qualitative study on profiling of suicidebombers suggests that out of total educated youth (males) some $70 \%$ are educated in public schools of Pakistan. According to Christine (2007) more than $60 \%$ of suicide-bombers in Pakistan had some form of formal (public) schooling.

\section{Final Considerations}

As result, the education system in Pakistan is not limited to public school system both in private and public sector. It is more than that. The question is where these 25 million (estimated figure) children go. Why they are called child labor, if they are no alternative is available to seek professional or vocational education at all? I share a couple of tables from my research to make it a case in formal education sector before dealing with these questions.

Table 1: Gender-based Distribution of Government and Private High Schools in Selected Districts.

\begin{tabular}{|c|c|c|c|c|c|c|}
\hline \multirow{2}{*}{ Gender } & \multicolumn{3}{|c|}{ Peshawar* } & \multicolumn{3}{c|}{ Mardan** } \\
\cline { 2 - 7 } & Government & Private & Total & Government & Private & Total \\
\hline Boys & 103 & 329 & 432 & 85 & 122 & 207 \\
\hline Girls & 50 & 232 & 282 & 50 & 82 & 132 \\
\hline Total & 153 & 561 & 714 & 135 & 204 & 339 \\
\hline
\end{tabular}

Sources: *Result Gazette: Secondary School Certificate 9th, 2012 Annual, Board of Intermediate and Secondary Education, Peshawar. Khyber Pakhtunkhwa.

Table 2: Gender Based Distribution of Students in Government and Private Schools in Two Districts of Khyber Pakhtunkhwa Province of Pakistan.

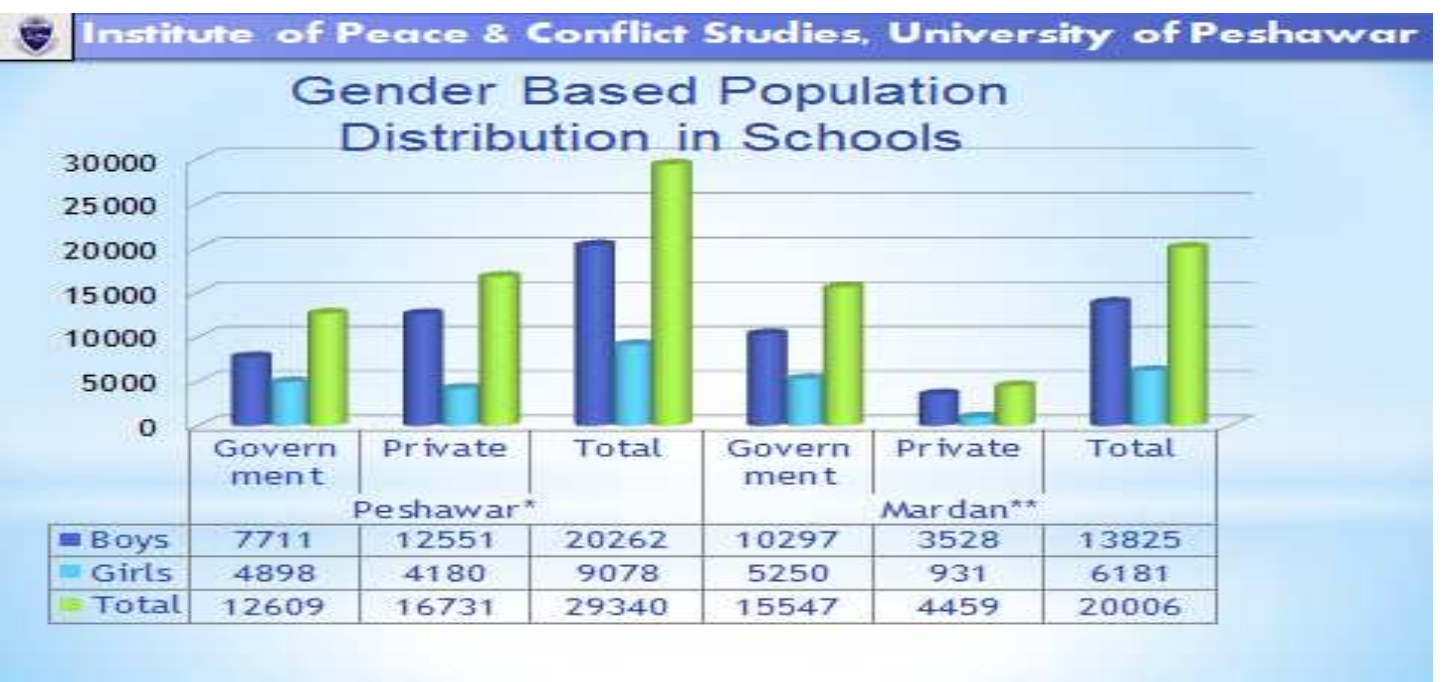

Sources: *Result Gazette: Secondary School Certificate 9th, 2012 Annual, Board of Intermediate and Secondary Education, Peshawar. Khyber Pakhtunkhwa. 
As table 1 and 2 shows in District Peshawar the total 29340 students study at 714 Schools, out of them 432 schools for boys and 282 are girls' schools. Out of these total 714 schools 561 are private schools and 153 are government Schools.

In District Peshawar the average number of students per in Grade 10 per school is thus 41.09 however if it is divided on single variable i.e. public and private; 82.41 students in grade 10 per school is in government sector and 29.82 in private sector. In District Mardan a total of 20006 students observed study in grade 10 at 339 Schools. Out of them 207 schools are for boys and 132 are for girls. Total private schools are 204 and 135 government Schools. In District Mardan the average number of students in grade 10 per school is 59.01 however, if it is separated 115.11 average students in grade 10 per school in government sector and 21.85 in private sector.

Gender based segregated data however, shows that schools both in public and private sector for female are half of those for male in the two districts. Similar are the facts for gender based enrollment.

\section{BIBLIOGRAPHIC REFERENCES:}

AMJAD, R.; MACLEOD, G. Effectiveness of Private, Public and Private-Public Partnership Schools in Pakistan, 2012.

ASER, F. Annual Status of Education Report, ASER Pakistan 2014. South Asian Forum for Education Development, Lahore, Pakistan, 2015.

COUNCIL, P. Pakistan: the next generation. British Council, 2009.

FAIR, C. C.; HARDIN, M. G. Does Pakistan Have a Madrasah Problem? Reconsidering the Securitization of Islamic Education in Pakistan, July 19, 2014.
MONTERO, David. Pakistan: The lost Generation. Accessed online at www.pbs.org/frontline/world/stories/Pakist an901/ video_index.html of 2010.

SATHAR, Z. A.;LLOYD, C. B.;METE, C.;UL HAQUE, M. Schooling Opportunities for Girls as a Stimulus for Fertility Change in Rural Pakistan. Economic Development and Cultural Change, 51(3), 677-698, 2003.

SHAH, D. Country report on decentralization in the education system of Pakistan: Policies and strategies. Islamabad: Academy of Educational Planning and Management,(Islamabad), Ministry of Education, 2003.

WITTE, S. S., EL-BASSEL, N., GILBERT, L., WU, E.; CHANG, M. Lack of awareness of partner STD risk among heterosexual couples. Perspectives on Sexual and Reproductive Health, 42(1), 49-55, 2010. 